Удк: 338.1:631.1

\title{
ТЕОРЕТИЧНО-МЕТОДИЧНІ ОСНОВИ ФОРМУВАННЯ ПОКАЗНИКІВ ОЦІНКИ СТАЛОГО РОЗВИТКУ ПІДПРИЄМНИЦТВА В СІЛЬСЬКОМУ ГОСПОДАРСТВІ
}

\author{
THEORETICAL AND METHODOLOGICAL BASIS \\ OF FORMATION OF INDICATORS OF ASSESSMENT \\ OF SUSTAINABLE DEVELOPMENT \\ OF ENTREPRENEURSHIP IN AGRICULTURE
}

\author{
Іванченко Віталій Олександрович \\ кандидат економічних наук, доцент, \\ Державне підприємство «Державний дорожній \\ науково-дослідний інститут імені М.П. Шульгіна» \\ ORCID: https://orcid.org/0000-0003-4014-0780 \\ Ivanchenko Vitalii \\ M.P. Shulgin State Road Research Institute State Enterprise
}

\begin{abstract}
Стаття присвячена актуальним питанням формування показників оцінки сталого розвитку підприємництва в сільському господарстві. Проаналізовано та систематизовано методологічні підходи до їх формування та на їх основі наведено основний алгоритм розрахунків показників оцінки сталого розвитку саме підприємництва в сільському господарстві. Ці показники розділено за окремими блоками на економічні, соціальні та екологічні, що надають можливість чітко відділяти окремі показники діяльності підприємництва в сільському господарстві за їх видами та кінцевими цілями. Крім цього, усю систему показників оцінки, розділено на п'ять етапів, що чітко розділяє та систематизує усі показники та покращує систему розрахунків й виявляє слабкі місця та проблем. Це дозволить оперативно реагувати на ситуацію та спрямувати діяльність підприємництва за системою сталого розвитку із реалізацією конкретних цілей цього процесу.
\end{abstract}

Ключові слова: сталий розвиток, підприємництво, сталий розвиток підприємництва, індикатори сталого розвитку, індекси сталого розвитку.

Статья посвящена актуальным вопросам формирования показателей оценки устойчивого развития предпринимательства в сельском хозяйстве. Проанализированы и систематизированы методологические подходы к их фрормированию и на этой основе представлены алгоритмы расчетов показателей оценки устойчивого развития именно предпринимательства в сельском хозяйстве. Эти показатели разделены по отдельным блокам на экономические, социальные и экологические, предоставляющие возможность анализировать показатели деятельности предпринимательства в сельском хозяйстве по их видам и конечными целями. Кроме этого, вся система показателей оценки, разделена на пять этапов, что четко систематизирует все показатели и улучшает систему расчетов и обнаруживает слабые места и проблем. Это позволит оперативно реагировать на ситуацию и направить деятельность предпринимательства по системе устойчивого развития с реализацией конкретных целей этого процесса.

Ключевые слова: Устойчивое развитие, предпринимательство, устойчивое развитие предпринимательства, индикаторы устойчивого развития, индексы устойчивого развития.

The article is devoted to topical issues of formation of indicators of assessment of sustainable development of entrepreneurship in agriculture. Despite the significant number of publications, some questions regarding the theoretical and methodological foundations of the formation of indicators for assessing the sustainable development of entrepreneurship in agriculture have not yet been covered and need research. Therefore, the main objectives of this publication are to reveal the theoretical and methodological features of the construction of indicators that characterize the process of sustainable development of entrepreneurship in agriculture. To solve this goal, methodological approaches to their formation were analyzed and systematized, and on their basis the main algorithm for calculating indicators for assessing the sustainable development of entrepreneurship in agriculture was presented. These indicators are divided into separate blocks into economic, social and environmental, which make it possible 
to clearly separate the individual indicators of entrepreneurial activity in agriculture by their types and ultimate goals. In addition, the whole system of evaluation indicators is divided into five stages. At the first stage, the main indicators for economic, social and environmental blocks are formed. On the second - the basic indicators of sustainable development are calculated. At the third stage, three main indices of sustainable development are calculated for each individual block of indicators. At the fourth stage, these indices form a separate index for each of the blocks indices of economic, social and environmental development of entrepreneurship. In the fifth stage, based on preliminary calculations, the general index of sustainable development of entrepreneurship in agriculture is determined. This approach to calculations will allow a clear division and systematization of all indicators, improve the calculation system, and identify weaknesses and problems. In addition, the system of distribution of assessment of sustainable development of entrepreneurship in agriculture by blocks and stages will quickly respond to the situation and direct the activities of entrepreneurship in the system of sustainable development with the implementation of specific objectives of this process.

Keywords: sustainable development, entrepreneurship, sustainable development of entrepreneurship, indicators of sustainable development, indices of sustainable development.

Постановка проблеми. На сьогодні концепція сталого розвитку стала визначальною у життєдіяльності суспільства. Одне із головних місць у забезпеченні цього процесу відіграє підприємництво, що працює в сільському господарстві [1; 2; 3]. Але, щоб з'ясувати, чи працює підприємництво за системою сталого розвитку чи ні, потрібно застосувати ряд критеріїв та характеристик, що можуть охарактеризувати цей процес. Серед найбільш розповсюджених методик аналізу зміни показників сталого розвитку використовують систему розрахунку індикаторів та індексів сталого розвитку.

Аналіз останніх досліджень і публікацій. Проблемі сталого розвитку увагу приділяли як закордонні, так і вітчизняні науковці. Серед них загальні питання сталого розвитку розкривали $[1 ; 4 ; 5 ; 6]$. Значної уваги приділяли науковці й питанню моніторингу та оцінці сталого розвитку, серед досліджень основними $\epsilon[7 ; 8 ; 9]$, крім цього окремо досліджували побудову індексів та індикаторів [8; 10; 11; 12].

Виділення невирішених раніше частин загальної проблеми. Але, незважаючи на значну кількість публікацій, частина питань стосовно теоретичних та методичних основ фрормування показників оцінки сталого розвитку саме підприємництва в сільському господарстві ще залишилася не висвітленою та потребує дослідження.

Формулювання цілей статті (постановка завдання). Головними завданнями цієї публікації $€$ розкриття теоретичних та методичних особливостей побудови показників, що характеризують процес сталого розвитку підприємництва в сільському господарстві.

Виклад основного матеріалу дослідження. Для характеристики процесу сталого розвитку підприємництва в сільському господарстві, постає питання оцінки цього процесу. Така оцінка потрібна для розробки опти- мальної стратегії діяльності підприємництва за системою сталого розвитку та виявлення основних проблем і шляхів їх вирішення на шляху до реалізації основних цілей визначених цією концепцією. Більшість науковців, під оцінкою процесу сталого розвитку, розуміють характеристику визначених показників за допомогою індексного методу. Наш підхід також базується на цій теорії, та визначає основних перелік показників, індикаторів та індексів, що характеризують процес сталого розвитку саме підприємництва в сільському господарстві.

Дослідження показників оцінки сталого розвитку підприємництва в сільському господарств доцільно проводити за блоками та окремими рівнями (рис. 1), що надасть можливість чітко відділити окремі показники для характеристики як економічної так і соціальної та екологічної діяльності підприємництва в сільському господарстві. Крім цього такий підхід надасть можливість виявити слабкі та вузькі місця в самому процесі сталого розвитку підприємництва, шляхів їх вирішення та окреслить майбутні перспективи.

Усі показники діляться на три основні частини - економічний, соціальний та екологічний блоки. Цей розподіл дозволить чітко відділить різні за характеристиками показники один від одного, та проаналізувати виконання поставлених конкретних завдань та сорормувати чіткі цілі для майбутнього забезпечення процесу сталого розвитку підприємництва в сільському господарстві.

Крім цього, для покращення системи розрахунків усі показники групуються також на розрахунки за рівнями. Визначено п'ять таких рівнів (рис. 1).

Перший рівень показників забезпечує фрормування вихідної інфрормації для проведення подальших розрахунків. На цьому рівні збирається уся статистична, фрінансова та опера- 


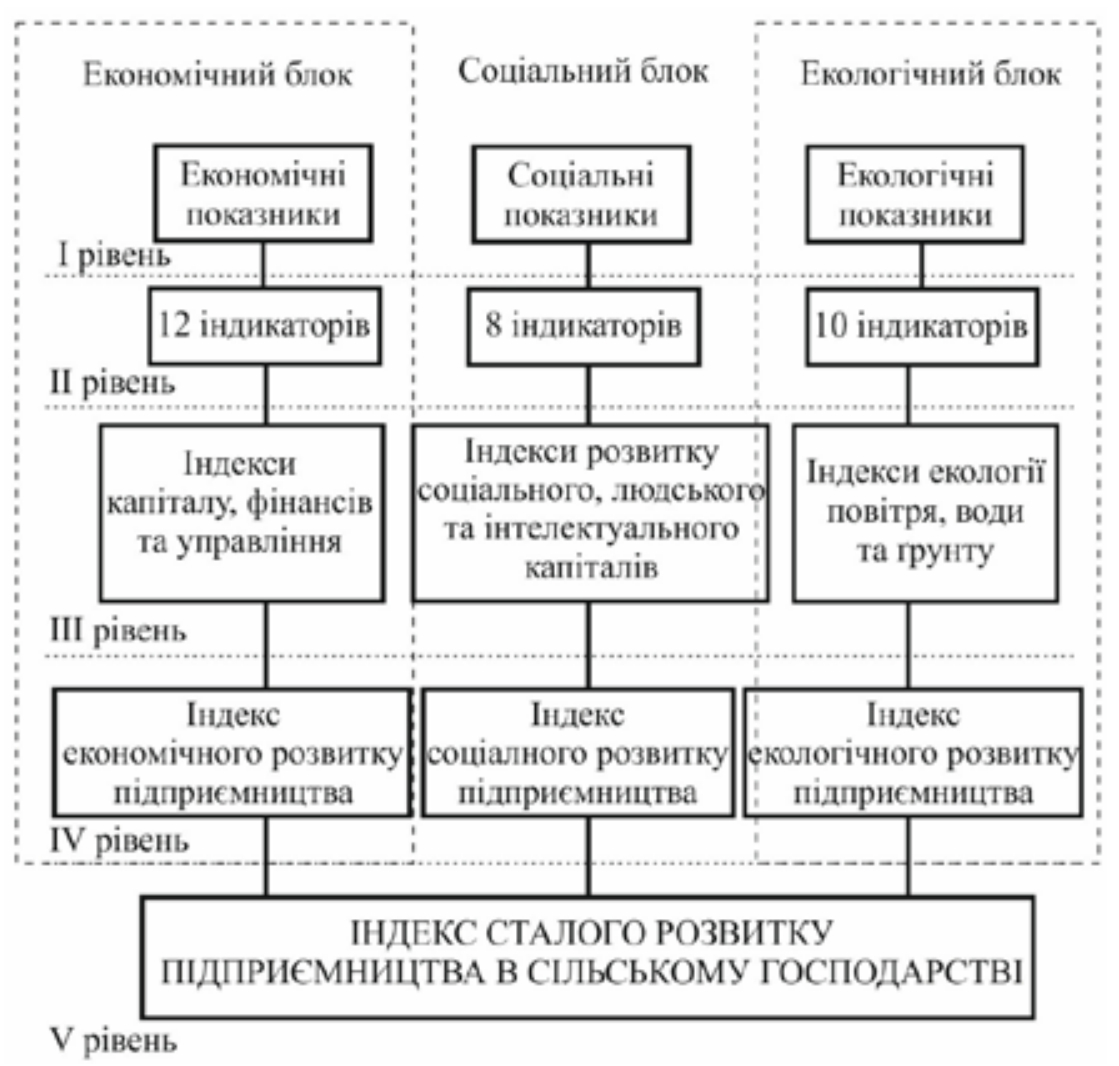

Рис. 1. Формування показників сталого розвитку
підприємництва в сільському господарстві

Джерело: розроблено автором

тивна інформація про діяльність підприємництва в сільському господарстві. Для кожного окремого блоку, такі показники матимуть окремий перелік, що за своєю наповненістю у повній мірі розкриє інформацію про забезпечення економічного, соціального та екологічного розвитку.

До показників першого рівня економічного блоку ми відносимо показники, що характеризують: кількість найманих працівників; заробітна плата найманого працівника; рівень додаткового доходу найманого працівника; рівень продуктивності праці в сільському господарстві; наявність основних засобів у підприємницьких структурах; рівень зносу основних засобів; рівень оновлення основних засобів; вартість вирощеної продукції підприємництвом в сільському господарстві; види вирощеної продукції підприємництвом у сільському господарстві; обсяг валової продукції; обсяг чистої продукції; рівень забезпечення оборотним капіталом; рівень забезпечення запасами; рівень дебіторської заборгованості, рівень кредиторської заборгованості; рівень забезпечення грошовими коштами; рівень наявності готової продукції на складах; частку орної землі в загальній кількості сільськогосподарських земель підприємництва в розрахунку на один господарюючий суб'єкт; частку багаторічних насаджень в загальній площі сільськогосподарських земель підприємництва в розрахунку на один господарюючий суб'єкт; частку орендованих та власних земельних площ; частку зрошуваних земель до загальної площі сільськогосподарських угідь в розрахунку на 1 господарюючий суб'єкт; структуру посівних площ; рівень урожайності сільськогосподарських культур, що вирощуються суб'єктами підприємництва; структуру витрат підприємництва сільського господарства; рівень витрат; рівень доходів підприємництва; рівень рентабельності; рівень валової доданої вартості; рівень капітальних інвестицій; рівень фрінансових інвестицій; рівень ефрективності інвестицій; об'єм реалізованої продукції.

До показників першого рівня соціального блоку ми відносимо показники, що характеризують: кількість підприємництва в сільському господарстві; наявність сільського населення; кількість приросту (скорочення) сільського населення; тривалість життя в сільській міс- 
цевості; кількість новонароджених в сільській місцевості; кількість новостворених підприємств за видом діяльності сільське господарство; кількість зареєстрованих фрізичних осіб-підприємців за видом діяльності сільське господарство; кількість нових робочих місць в сільському господарстві; показники рівня заробітної плати в сільському господарстві; показники рівня доходу фрізичних осіб-підприємців, що працюють в сільському господарстві; гендерні показники людського капіталу в сільському господарстві; показники травматизму в сільському господарстві; показники рівня освіти та рівня підвищення кваліфрікації працівників сільського господарства.

До показників першого рівня екологічного блоку ми відносимо показники, що характеризують: кількість підприємництва в сільському господарстві; площу сільськогосподарських угідь; площу ріллі; наявність гумусу у ґрунті; еродованість ґрунтів; питому вагу зрошуваних земель; питому вагу осушених земель; показники родючості вирощених сільськогосподарських культур з досліджуваних ділянок; середній бал родючості орних ґрунтів; площу порушених чи рекультивованих земель; площу лісового фонду та заповідні території; обсяги вапнування та гіпсування ґрунтів; обсяги розораності земель та сільгоспугідь; питому вагу посівних площ в складі ріллі; питому вагу удобрених площ; об'єми внесення органічних та мінеральних добрив; питому вагу площі посівів інтенсивних культур в загальній площі посівів; наявність промислових токсичних відходів у розрахунку на один кілометр квадратний; надходження забруднюючих речовин у земельні ресурси; створення полезахисних лісових смуг.

У деякій мірі показники першого рівня поєднуються та перекликаються між економічним, соціальним та екологічним блоками, та при цьому, у своїй більшості, вони застосовуються для окремих специорічних характеристик за вимогами конкретного блоку та $€$ спеціальними для підприємництва, що працює в сільському господарстві.

На базі показників першого рівня, які зазвичай не можна використовувати для інтерпретації змін, в подальшому фрормуються та розраховуються показники другого рівня індикатори кожного окремого блоку. Ці індикатори нададуть змогу судити про стан або зміни економічної, соціальної чи екологічної змінної. Основною метою введення індикаторів є оцінка ситуації або події, для прогнозу розвитку ситуації, що склалася, і розробки її вирішення. Для характеристики показників другого рівня економічного блоку доцільно використати 12 індикаторів, а саме:

1. Показник ВВП сільськогосподарської продукції, що виробляється в сільському господарстві.

2. Показник продуктивності сільського господарства.

3. Показник рентабельності сільського господарства.

4. Показник експорту сільськогосподарської продукції.

5. Показник кількості новоствореного виробництва в сільському господарстві.

6. Показник оновлення основних засобів підприємництва в сільському господарстві.

7. Показник рівня зносу (амортизації) основних засобів підприємництва.

8. Показник зменшення використання ресурсів у сільському господарстві.

9. Показник використання у виробництві продукції сільського господарства.

10. Показник рівня втрат продукції сільського господарства.

11. Показник кількості збудованих складських приміщень.

12. Рівень інвестицій в сільське господарство.

Для характеристики показників другого рівня соціального блоку доцільно використати 8 індикаторів, а саме:

1. Кількості новостворених підприємств та зареєстрованих орізичних осіб-підприємців, що працюють в сільському господарстві.

2. Кількості нових робочих місць в сільському господарстві.

3. Рівня заробітної плати в підприємствах сільського господарства.

4. Рівня доходу фрізичних осіб-підприємців та господарства населення.

5. Кількості зайнятих жінок у сільському господарстві та жінок-господарів сільськогосподарських підприємств.

6. Травматизму в сільському господарстві.

7. Підвищення кваліфрікації працівниками сільськогосподарського підприємництва.

8. Рівня впровадження інновацій в сільськогосподарське виробництво.

Серед екологічних індикаторів, що знаходяться на II рівні доцільно виділити:

1. Кількості сільськогосподарських угідь, їх збільшення чи зменшення.

2. Обсяги використання хімічних речовин у ґрунті, воді та повітрі.

3. Застосування ощадливих технологій у вирощуванні продукції.

4. Об'єми викидів шкідливих речовин у повітря, воду та ґрунт. 
5. Застосування еколого чистих технологій та вирощення еколого чистої продукції.

6. Об'єми використання води.

7. Приріст кількості водоочисних споруд.

8. Об'єми застосування систем крапельного зрошення.

9. Об'єми використання альтернативного палива.

10. Обсяги застосування відновлювальної енергетики у сільському господарстві.

Базуючись на показниках індикаторів розраховують індекси для кожного блоку окремо. Розрахунки індексів уведено для відображення рівня змін показників що характеризуються, за періоди, що обрані для порівняння. Для кожного блоку індекси також було розділено на три складові. Так, для економічного блоку на третьому рівні індекси розраховують за групами капітал, фрінанси та управління. Для соціального блоку - на індекси соціального, людського та інтелектуального капіталів. Для екологічного блоку - індекси повітря, ґрунту та води. Поділ цих індексів на групи надає можливість чітко та якісно побудувати управління своєю управлінською структурою плануючи діяльність за чіткими групами, та при необхідності заздалегідь визначитись із рішенням проблеми, якщо вона виникає.

Розрахунок кожного із зазначених індексів базується на єдиному підході в методиці розрахунків. Узагальнюючі показники розраховуємо як сума відношення звітного періоду до попереднього показників індикаторів відповідної категорії показників, які відносяться до групи індексів, для яких він розраховується, в розрахунку на 1 га сільськогосподарських угідь, що обробляє підприємництво в сільському господарстві (фрормула 1).

$$
I_{n}=\sum_{n} \frac{q_{i}{ }^{*} i_{n}^{\text {ek.tp }}}{i_{n-1}^{e \kappa . r p}}
$$

де $I_{n}$ - Індекс окремої групи, що розраховується, од;

$i_{n}^{j}$ - Індикатори, що входять до індексу який розраховують, од;

$n$ - період, що досліджується;

$q_{i}$ - ваговий коесріцієнт індикатора в загальному розрахунку індексу сталого розвитку підприємництва в сільському господарстві (розраховується окремо для кожного індикатора).

щоб вирівняти нерівномірний вплив кожного окремого показника на кінцевий результат, було прийнято рішення до складу розрахунків включити ваговий коесріцієнт індикатора в загальному розрахунку індексу сталого розвитку підприємництва в сільському господарстві.
На четвертому етапі, після розрахунку індексів для кожного окремого блоку (економічного, соціального та екологічного), проводимо розрахунок показників складових сталого розвитку, а саме індексів економічного, соціального та екологічного розвитку підприємництва. Ці показники розраховуються як добуток трьох індексів, що були визначені на третьому етапі у кожному окремому блоці.

Далі, на основі отриманих параметрів індексів економічного, соціального та екологічного розвитку розраховуємо показник сталого розвитку підприємництва в сільському господарстві. Базуючись на методології, розробленій та висвітленій в [13] та зберігаючи загальнонаціональний підхід в розрахунках індексу сталого розвитку, фрормула розрахунку індексу сталого розвитку підприємництва в сільському господарстві матиме наступний вигляд:

$$
I_{\text {Cm.P.Піо }}=\sqrt{\left(I_{\text {Ек.Роз }}{ }^{2}+I_{\text {Соน.Роз }}{ }^{2}+I_{\text {Екн.СК. }}{ }^{2}\right)}
$$

де $I_{\text {ст.р.пір }}$ - Індекс сталого розвитку підприємництва в сільському господарстві, од.

$I_{\text {Ек.Роз }}$ - Індекс екологічного розвитку підприємництва в сільському господарстві, од.

$I_{\text {соц.Роз }}$ І Індекс соціального розвитку підприємництва, од.

$I_{\text {Екн.ск }}$ - Індекс економічного розвитку підприємництва в сільському господарстві, од.

За наведеним алгоритмом, рівень сталого розвитку підприємництва в сільському господарств і можливо розділити на низький, середній та високий. За шкалою розподілу ці рівні можливо виділити як низький - від 0,0 до 0,9, середні - від 0,901 до 1,800, та високий від 1,801 до 3,0

Усі індекси побудовані за методами інтегральних та агрегованих індексів, що надає комплексну інформацію про розвиток підприємництва в сільському господарстві та країни в цілому. Найбільш інформативними, що надають інформацію про загальний стан розвитку підприємництва в сільському господарстві $\epsilon$ індекс сталого розвитку підприємництва. Він характеризує зміну стану підприємництва в сільському господарстві, 3 урахуванням впливу розвитку підприємництва на екологію, розвитку соціального та людського капіталів у складі підприємництва сільського господарства та економічного розвитку підприємництва.

Висновки. Отже, фрормування показників оцінки сталого розвитку підприємництва в сільському господарстві починається із їх розподілу за окремими блоками на еконо- 
мічні, соціальні та екологічні, що надасть можливість чітко відділяти окремі показники діяльності підприємництва в сільському господарстві за їх видами та кінцевими цілями. Крім цього, усю систему показників оцінки, розділено на п'ять етапів, що чітко розділяє та систематизує усі показники та покращує систему розрахунків й виявляє слабкі місця та проблем. Такий підхід дозволяє оперативно реагувати на ситуацію та прямувати діяльність підприємництва в сільському господарстві чітко за системою сталого розвитку із реалізацією конкретних цілей цього процесу.

\section{СПИСОК ВИКОРИСТАНИХ ДЖЕРЕЛ:}

1. Лєбєдєв І. Сталий розвиток туризму: досвід Європейського союзу і завдання для України. Вісник соціально-економічних досліджень. 2018. № 3(67). С. 162-173.

2. Лузан О. Ю. До питання фрормування механізму інституційного забезпечення сталого розвитку аграрного підприємництва. Економіка АПК. 2014. № 4. С. 106-111.

3. Кісіль М. І., Гарбар В. В. Теоретичні та практичні аспекти формування стратегій сталого розвитку фермерських господарств. Економіка АПК. 2015. № 12. С. 35-43.

4. Salas-zapata Walter Alfredo, Ortiz-muñoz Sara Milena. Analysis of meanings of the concept of sustainability. Sustainable Development. 2019. № 27(1). Pp. 153-161.

5. Silvius Gilbert. Sustainability as a new school of thought in project management. Journal of Cleaner Production. 2017. № 166. Pp. 1479-1493.

6. Лупенко Ю. О. Стан та перспективи сталого розвитку сільських територій. Економіка АПК. 2017. № 6. C. 7-10.

7. Sun Huaping, et al. Measuring environmental sustainability performance of South Asia. Journal of Cleaner Production. 2020. № 251. Pp. 119.

8. Котикова О. І. Моніторинг та оцінка сталості розвитку сільськогосподарського землекористування регіонів України. Економіка АПК. 2017. № 5. С. 24-32.

9. Тихонов А. Г., Гребенюк Н. В., Тихоненко О. В. Наукові засади сталого розвитку землекористування: індикація екологічного. Землевпорядкування. 2003. № 1. С. 15-20.

10. Лупенко Ю. О., Малік М. Й., Булавка О. Г. та ін. Стратегічні напрями сталого розвитку сільських територій на період до 2030 року. Київ : ННЦ IAE, 2020. 60 c.

11. Casini M., et al. Sustainable Development Goals indicators: A methodological proposal for a Multidimensional Fuzzy Index in the Mediterranean area. Sustainability. 2019. № 11(4). Pp. 1198.

12. Kilkiş Ş. Sustainable development of energy, water and environment systems index for Southeast European cities. Journal of cleaner production. 2016. № 130. Pp. 222-234.

13. Згурський М. З. Сталий розвиток регіонів України. Київ : НТУУ «КП|», 2009. 197 с.

\section{REFERENCES:}

1. Lyebyedyev, I. (2018) Stalyy rozvytok turyzmu: dosvid Yevropeyskoho soyuzu i zavdannya dlya Ukrayiny [Sustainable development of tourism: the experience of the European Union and the challenges for Ukraine]. Visnyk sotsialno-ekonomichnykh doslidzhen, vol. 3.67, pp. 162-173. (in Ukrainian)

2. Luzan, O. Yu. (2014) Do pytannya formuvannya mekhanizmu instytutsiynoho zabezpechennya staloho rozvytku ahrarnoho pidpryyemnytstva [On the formation of the mechanism of institutional support for sustainable development of agricultural entrepreneurship]. Ekonomika APK, vol. 4, pp. 106-111. (in Ukrainian)

3. Kisil, M. I. and Harbar, V. V. (2015) Teoretychni ta praktychni aspekty formuvannya stratehiy staloho rozvytku fermerskykh hospodarstv [Theoretical and practical aspects of the formation of strategies for sustainable development of farms]. Ekonomika APK, vol. 12, pp. 35-43. (in Ukrainian)

4. Salas-zapata, Walter Alfredo and Ortiz-muñoz, Sara Milena (2019) Analysis of meanings of the concept of sustainability. Sustainable Development, vol. 27.1, pp. 153-161.

5. Silvius, Gilbert (2017) Sustainability as a new school of thought in project management. Journal of Cleaner Production, vol. 166, pp. 1479-1493.

6. Lupenko, Yu. O. (2017) Stan ta perspektyvy staloho rozvytku silskykh terytoriy [State and prospects of sustainable development of rural areas]. Ekonomika APK, vol. 6, pp. 7-10. (in Ukrainian)

7. Sun, Huaping, et al. (2020) Measuring environmental sustainability performance of South Asia. Journal of Cleaner Production, vol. 251, p. 119. 
8. Kotykova, O. I. (2017) Monitorynh ta otsinka stalosti rozvytku silskohospodarskoho zemlekorystuvannya rehioniv Ukrayiny [Monitoring and assessment of sustainability of agricultural land use in the regions of Ukraine]. Ekonomika APK, vol. 5, pp. 24-32. (in Ukrainian)

9. Tykhonov, A. H., Hrebenyuk, N. V. and Tykhonenko, O. V. (2003) Naukovi zasady staloho rozvytku zemlekorystuvannya: indykatsiya ekolohichnoho [Scientific principles of sustainable development of land use: an indication of ecological]. Zemlevporyadkuvannya, vol. 1, pp. 15-20. (in Ukrainian)

10. Lupenko, Yu. O., Malik, M. Y., Bulavka O. H., ta in. (2020) Stratehichni napryamy staloho rozvytku silskykh terytoriy na period do 2030 roku [Strategic directions of sustainable development of rural areas for the period up to 2030]. Kyiv: NNTS IAE, 60 p. (in Ukrainian)

11. Casini, M., et al. (2019) Sustainable Development Goals indicators: A methodological proposal for a Multidimensional Fuzzy Index in the Mediterranean area. Sustainability, vol. 11.4, p. 1198.

12. Kilkiş Ş. (2016) Sustainable development of energy, water and environment systems index for Southeast European cities. Journal of cleaner production, vol. 130, pp. 222-234.

13. Zhursky, M. Z. (2009) Stalyy rozvytok rehioniv Ukrayiny [Sustainable development of the regions of Ukraine]. Kyiv: NTUU «KPI», 197 p. (in Ukrainian) 